\title{
Oral Squamous Papilloma of the Palate- A Case Report
}

\author{
Saraswathi Naik ${ }^{1}$, Madhumati Nidoni ${ }^{2}$ \\ ${ }^{1}$ Bapuji Dental College and Hospital, Davengere, Karnataka \\ ${ }^{2} \mathrm{Sjm}$ Dental College and Hospital, Chitradurga
}

Received October 10, 2014; Revised October 27, 2014; Accepted December 18, 2014

\begin{abstract}
Oral squamous Papillomas appear as pedunculated or sessile, white or normal colored cauliflowerlike projections that arise from the mucosal surface. The most common site is the palateuvula area followed by tongue and lips. The etiology remains unknown. Conservative surgical excision is the treatment of choice with rare recurrence. There is no evidence that papillomas are premalignant.
\end{abstract}

Keywords: squamous papilloma, human papilloma virus, pedunculated, excisional biopsy

Cite This Article: Saraswathi Naik, and Madhumati Nidoni, "Oral Squamous Papilloma of the Palate- A Case Report." International Journal of Dental Sciences and Research, vol. 2, no. 6B (2014): 17-18. doi: 10.12691/ijdsr-2-6B-5.

\section{Introduction}

Oral squamous papillomas(OSP) are common lesions of the oral mucosa. It is a benign proliferation of the stratified squamous epithelium, which results in a papillary or verrucous exophytic mass. The sites of predilection for localization of the lesions include the tongue and soft palate, but any surface of the oral cavity can be affected. In recent years, a clear connection has been established between human papillomavirus (HPV) and the development of squamous papilloma [1]. The squamous papilloma is associated with human papilloma virus (HPV) types 6 and 11 [2]. The primary means of HPV transmission to children is the ingestion of viral particles of infected cells from the birth canal, whereas in adults HPV is mainly transmitted through sexual contact. They typically present as single pedunculated masses with numerous fingerlike projections at the surface [3].

We present a case of recurrent squamous papilloma in the form of oral lesion.

\section{Case Report}

An 11 year old female patient reported to the department of pedodontics and preventive dentistry, College of dental sciences, Davangere, with the chief complaint of a growth on the right side of the palate since 7-8 months and History revealed that the growth started as small finger like projections and attained the present size with 4-5 moths. She also gave the history of same type of growth on the palate 3 years back and which she got it excised in a private clinic. She also complained of burning sensation while intake of food. A thorough clinical examination revealed a pedunculated cauliflower like growth on the hard palate of size around 8 X $10 \mathrm{~mm}$. 1215 pink finger like projections was noticed and it was tender, as it interfered with the occlusion. A provisional diagnosis of Oral Squamous papilloma was made and excisional biopsy was planned.

A complete surgical excision up to $1 \mathrm{~mm}$ margin to the depth of the submucosa and a small area of surrounding normal tissue was done and patient was recalled after 1 week. But patient didn't report back to the college. After excisional biopsy of the lesion, the specimens were fixed and stained with hematoxylin eosin, for routine histological analysis. The strict histopathologic criteria for oral squamous papilloma (OSP) is as follows: squamous epithelium arrayed in finger-like projections, normal maturation pattern and presence of hyperparakeratosis in the epithelium, koilocytosis as a result of perinuclear cytoplasmic vacuolization of cells of the spinous layer of the epithelium, producing perinuclear pale/clear halos, and pyknosis and the occasional presence of basilar hyperplasia [4].

\section{Discussion}

The association between HPV and squamous cell lesions at various sites of the body, including the oral cavity, was first described by Syrjänen et al. 25, in 1983 [5]. Human papillomaviruses (HPVs) are a group of hostspecific DNA viruses, with remarkable epithelial cell specificity: they have been reported principally in the anogenital tract, urethra, skin, larynx, trachea bronchial and oral mucosa.

Papilloma viruses are members of the Papillomavirus family and together with Polyomaviruses form the species Papovaviridae. Papillary lesions are tumefactive with a cauliflower like surface. Some are pedunculated others are sessile. Some are single; others are multiple or diffusely involve broad areas of the oral mucosa. They occur at any age and are frequently seen in children and adolescents.

In general, oral mucosal papillomas are only mildly contagious and transmission requires direct mucosal contact. Viral transfer or inoculation to another individual probably requires an erosion or laceration of the 
recipient's mucosal epithelium for virus to gain access to the basal cells of the stratified epithelium.

Squamous papilloma is the most common benign epithelial neoplasm of oral epithelium. In the oral cavity, papillomas most commonly occur on the palate (34\%), but may also affect the uvula, tongue, lips and gingiva. Nonkeratinized lesions appear coral pink; if keratinized, they are white. Unlike squamous papillomas of the larynx, squamous papillomas of the oral cavity are not associated with cancer and rarely recur. Surgical removal is the treatment of choice and can be performed with electrocautery, cold-steel excision, laser ablation, cryosurgery, or intralesional injections of interferon [6].

\section{Conclusion}

Although recurrence is uncommon, except for lesions in patients infected with human immunodeficiency virus (HIV) [7], but in this present case recurrence has occurred reason being unknown.

\section{References}

[1] Crissman JD, Kessis T, Shah KV, Fu YS, Stoler MH, Zarbo RJ, et al. (1988). Squamous papillary neoplasia of the adult upper aerodigestive tract. Hum Pathol, 19(12): 1387-1396.

[2] Major T, Szarka K, Sziklai I, Gergely L, Czegledy J(2005). The characteristics of human papillomavirus DNA in head and neck cancers and papillomas. J Clin Pathol, 58(1): 51-55.

[3] P.W. Flint, B.H.Haughey, V. J. Lund et al., "Benign neoplasms," in Cummings Otolaryngology-Head and Neck Surgery, Elsevier Mosby, Philadelphia, Pa, USA, 5th edition, 2010.

[4] Oliveira MC, Silveira EJD, Godoy GP, Amorim RFB, Costa ALL, Queiroz LMG (2005) Immunohistochemical evaluation of intermediate filament proteins in squamous papilloma and oral verrucous carcinoma. Oral Dis 11, 288-292.

[5] Syrjänen K, Syrjänen S, Lamberg M, Pyrhönen S, Nuutinen J. Morphological and immunohistochemical evidence suggesting human papillomavirus (HPV) involvement in oral squamous cell carcinogenesis. Int J Oral Surg 1983; 12: 418-24.

[6] P. P. Jaju, P. V. Suvarna, and R. S. Desai, "Squamous pailloma: case report and literature review," International Journal of Oral Science, vol. 2, no. 4, pp. 222-225, 2010.

[7] Carneiro T, Marinho SA, Verli FD, Mesquita ATM, Lima NL, Miranda JL (2009). Oral squamous papilloma: clinical, histologic and immunohistochemical analyses. J Oral Sci, 51(3): 367-372. 